\title{
Applying Havruta Learning Method in Higher Education for Higher Student Engagement
}

\author{
Pyong Ho Kim ${ }^{1}$ \\ ${ }^{1}$ College of Liberal Arts and Interdisciplinary Studies, Kyonggi University \\ 154-42 Gwanggyosan-ro, Yeongtong-gu, Suwon-si, Gyeonggi-do, 16227, Korea \\ phkim@kgu.ac.kr
}

\begin{abstract}
Because Korean students in higher education setting tend to inactively and passively participate in class discussion, instructors face a number of difficulties related to this matter. A paired learning pedagogy, havruta learning, was proposed in the present study in order to overcome such an issue. 264 freshman college students took an elective course for a semester during which the instructor applied the havruta method. Its three core ideas included articulating, wondering, and challenging. 23 students answered to a series of five(5) short answers regarding what impressions they attained, particularly about the implementation of havruta learning method. It came out that the students appreciated the contented delivered in an organized fashion, and felt more attracted to engage in class discussion with their peers more actively. A few implications were made based on its findings, namely the importance of speaking for learning, as well as creating an enticing and welcoming environment in which students are motivated to do so.
\end{abstract}

Keywords: Havruta learning, Higher Education, Teaching methods, Student participation, Learning by talking

\section{Introduction: Statement of the Problem}

Most of Korean parents enthusiastically pursuit for their children's education. A number of Korean students attempt to meet their parents' expectations, bearing a tremendous amount of pressure. Since both students and parents have a strong belief that acquiring advanced education is the best method to achieve success in life, college entrance is an essential issue for them [1].

After being accepted to a college, a new problem emerges; because most students are accustomed to passively receive information that the instructors convey during K-12 schooling, they tend to show rather inactive attitudes in higher education, barely asking questions to their instructors. In fact, when an instructor asks if the class has a question regarding the contents of the day's lecture, one can easily find the students keeping themselves quiet.

A number of factors could explain such phenomena. Kim(2015) has suggested that college students generally do not appreciate unilateral lectures because it does not necessarily engage students in learning, nor does it give an impression that the instructor respects them [2]. It would be more reasonable as well as responsible for instructors to attempt heightening professor-student engagement during lectures.

One could easily understand that a growing interest among college professors in effectively having students actively participate in classes[3]. To resolve such difficulties, the purpose of the current study was to introduce havruta learning, a form of traditional Jewish studying method in which two people work together to closely read texts and

Received (May 20, 2018), Review Result (August 10, 2018), Accepted (August 20, 2018) 
interpret in a meaningful and engaging way [4]. The current study sought to answer the following two research questions.

Research Question 1: What educational benefits do students attain from havruta learning method during the course?

Research Question 2: What modifications should be applied in order to improve students' havruta experience?

\section{Related Researches}

\subsection{Defining and Implementing Havruta}

Havruta is a prevailing pedagogy in which pairs co-work to decipher connotation in the text they read [5]. Traditionally, the students have texts before them, and engage in debates over the given meaning in the texts $[6,7]$. Since this method establishes a premise that students can learn through their own argument, discussion, questioning-answering procedures, it often contradicts with how a typical structure of college lecture approaches in which the instructor takes the most of speaking part in every class [6]. It is understandable that when havruta is newly implemented in a college class setting, students and instructor may struggle with and encounter unnecessary or unexpected problems.

\subsection{Educational Benefits}

Havruta is known to offer learners intellectual space to verbally reflect on given passage with a partner [6]. By supporting and challenging each other's thinking, partners could actively build their understanding of the texts, which is a factor that moves responsibility from instructor to students [5]. It also helps heighten comprehension because partners could work together to help each other and overcome difficulties they may encounter during the conversation [5]. Havruta is known to support participants to engage in meaningful conversations regarding the text and to practice speaking and listening. Furthermore, once students have discussed with a partner about given texts, they are more likely to share their ideas with the others, serving as a 'precursor' to a wholeclass discussion [8].

\section{Methods}

\subsection{Study Setting}

The current study was conducted in a four-year university located in Gyeonggi Providence in South Korea. A total of 264 freshman students took a course entitled Pursuit of Truth instructed by the researcher in five different classes, in which havruta learning method was implemented as a core practice. The course was 15-week-long, and each week consisted of two hours of lecture. First week was devoted to introduce the course as well as the rationale of havruta, and eighth and $15^{\text {th }}$ weeks were used for midterm and final examinations, respectively, which leaves a total of 12 weeks of lectures. After 25 to 30 minutes of a unidirectional lecture delivered, the students were given a certain period of time to discuss over each topic during which they mainly practiced havruta.

\subsection{Study Materials}

The current study applied two types of discussion questions for the paired learning. First, organizing type was designed to help students intellectually (re)arrange the contents they receive during the lecture. Students were encouraged respond to the questions 
without relying materials (e.g., handouts, printed Power Point slides, textbook, smartphones, etc.). The instructor told the students to "explain as if a tutor explains it to a tutee". Second, opposing type was supposed to have students debate with his or her partner. The questions were designed so that a partner takes one side, while another partner does the other(e.g., "Is it justifiable to sacrifice animals as long as they contribute to advance of science?"). Student A took the "yes" side, while student B taking the "no" side, and argued over the given issue. After five minutes have passed, the instructor told the students to switch their position for each student to debate from both sides. [Table 1] shows a few example questions of both discussion types that the students used.

Table 1. A Few Examples of Questions based on the Discussion Type

\begin{tabular}{|c|c|c|}
\hline $\begin{array}{l}\text { Discussion } \\
\text { Type }\end{array}$ & Week(Title) & Questions \\
\hline \multirow{3}{*}{ Organizing } & 3 (Learning ) & $\begin{array}{l}\text { - How do I define 'neuroplasticity'? } \\
\text { - What are the two important features of metacognition? }\end{array}$ \\
\hline & 7 (Science) & $\begin{array}{l}\text { - What is an example that illustrates "correlation is not } \\
\text { causality"? } \\
\text { - What is the role of 'coincidence' in science? }\end{array}$ \\
\hline & 12 (Futurology) & $\begin{array}{l}\text { - Can you name four representative technology issues of the } \\
\text { fourth industrial revolution? } \\
\text { - What keywords can we use to describe first to third } \\
\text { industrial revolutions? }\end{array}$ \\
\hline \multirow{3}{*}{ Opposing } & 5 (Humanities) & $\begin{array}{l}\text { - Would it be a better idea not to teach humanity course in } \\
\text { colleges anymore? } \\
\text { - What are some pros and cons of teaching humanities in } \\
\text { colleges? }\end{array}$ \\
\hline & $\begin{array}{l}10 \text { (Ethical } \\
\text { Issues) }\end{array}$ & $\begin{array}{l}\text { - Which one comes first: human rights, or advance of } \\
\text { science? } \\
\text { - Is it justifiable to sacrifice animals as long as they } \\
\text { contribute to advance of science? }\end{array}$ \\
\hline & 14 (Happiness) & $\begin{array}{l}\text { - If money brings happiness, why do some rich individuals } \\
\text { commit suicide? } \\
\text { - Is my happiness worth of sacrificing the others'? }\end{array}$ \\
\hline
\end{tabular}

Additionally, toward the end of the semester, 23 student participants answered the following series of short open-ended questions in order to more deeply analyze the educational impact of havruta learning. Table 2 contains its detailed questions.

Table 2. Five Short Questions Regarding Students' havruta Experience during the Course

\begin{tabular}{|c|c|l|}
\hline Number & Title & \multicolumn{1}{|c|}{ Question } \\
\hline 1 & $\begin{array}{c}\text { Havruta } \\
\text { Experience }\end{array}$ & $\begin{array}{l}\text { Have you ever taken a course in which havruta approach was } \\
\text { implemented? }\end{array}$ \\
\hline 2 & $\begin{array}{c}\text { Preventing } \\
\text { Factors }\end{array}$ & $\begin{array}{l}\text { In your opinion, what factors prevent the course from having havruta } \\
\text { approach to be implemented? }\end{array}$ \\
\hline 3 & $\begin{array}{c}\text { Educational } \\
\text { Benefits }\end{array}$ & $\begin{array}{l}\text { In your opinion, what are few educational benefits you could earn from } \\
\text { implementing havruta approach? }\end{array}$ \\
\hline 4 & $\begin{array}{c}\text { Partner's } \\
\text { Activeness }\end{array}$ & Did your partner actively participate in conversation? Why, or why not? \\
\hline 5 & Suggestions & $\begin{array}{l}\text { What would be helpful in order to foster havruta approach if } \\
\text { implemented in the next semester? }\end{array}$ \\
\hline
\end{tabular}




\section{Results}

\subsection{Havruta Experience}

Out of 23 freshman participants, only six responded that they have taken a class where havruta learning approach was implemented. This is not a surprising finding, considering the fact that most high school classes in South Korea focus on rote memorization in a unidirectional teaching fashion. In fact, it was their first course taken in higher education setting.

\subsection{Preventing Factors}

The followings contain a few notable comments from students regarding factors that could prevent the course from effectively having havruta approach to be implemented.

"Not really. Though other students' voices were sometimes distracting, I could just focus on my conversation with my partner." - Student \#15 -

"When the partner is someone you know very well, the conversation could be loose, talking about other stuff." - Student \#10 -

"When the partner doesn't want to talk, it's really hard to carry on." - Student \#21 $-$

"The given time to talk about it is too short or too long." - Student \#23 -

"It's not a block factor, per se, but if the atmosphere of the class is not supportive, it's hard to focus on discussion" - Student \#1 -

\subsection{Educational Benefits}

The followings contain a few notable comments from students regarding educational benefits they observed.

“When I get to 'speak out' what I've learned during the lecture, I could exactly find out whether I knew the contents or didn't. Because I kept talking, I could not fall asleep during the lecture. It also helps me remember things better and raise up my grades." - Student \#4 -

"I've learned that it become my own knowledge when I'm able to explain it to the others. One benefit was that I could remember the contents more than I just memorized for myself." - Student \#8 -

"I could understand the contents more easily, and the memory lasts longer." Student \#9-

"I could clearly distinguish what I know from what I don't know. Also I could organize my learning by explaining to another." - Student \#14 -

"I was surprised that I could accept my partners' opposing ideas without much resistance. Also, I learned how to express my opposing ideas without hurting each other's feeling." - Student \#9- 


\subsection{Partner's Activeness}

The followings contain a few notable comments from students regarding how actively the partner(s) participated in conversation.

"My partner wasn't so helpful. Maybe s/he didn't think this method would be helpful."

- Student \#18 -

"My partner wasn't so supportive because she had no big interests in the subjects we talked about. I was the only one who liked it" - Student \# 22 -

"She participated well. It almost seemed as if she enjoyed explaining me things she understood during the lecture." - Student \#20 -

"I believe my partner appreciated this method because he could understand the contents better while explaining to each other." - Student \# 12 -

\subsection{Suggestions}

The followings contain a few notable comments from students regarding how havruta approach could be enhanced when implemented in the next semester.

"If the partners are chosen randomly, it might be helpful." - Student \#14 -

"If the instructor gave some example questions in advance, that could help us to come up with similar questions" - Student \# 10 -

"Talking among a few students is better idea than talking among many." - Student \#13-

"I'm not sure how to change someone's unsupportive attitude." - Student \#8 -

\section{Conclusions}

Although most of student participants previously had not experienced havruta learning in education settings, they seemed to appreciate this method, and received a number of educational benefits from it. For example, the students responded that they could intellectually arrange the contents delivered during the lecture in an organized fashion because they had experienced articulating it with a partner, resulting in better memorization. Also, they expressed that lecture contents became their own knowledge as they had verbally explained to another. This outcome was possible mainly because they could distinguish 'what they actually know' from 'what they thought they knew'. Once students found the areas of knowledge they need improvement, they could invest most time for studying on those specific ones. Furthermore, students appeared to learn exchanging opposing ideas with one another on controversial issues; this is a particularly an appealing feature because there exist cultural norms that make students feel difficult to become open to others' opposing ideas [4].

In order for instructors to keep these positive outcomes available, the findings suggest a few implications. First, students need to learn the importance of verbally discussing the lecture contents for better learning outcomes. Second, the instructors need to create a comfort and inviting atmosphere for students to actively engage in the discussion. 


\section{References}

[1] N. Park and J. Weidman, "Higher Education in Korea: Tradition and Adaptation", Routledge, (2002), pp. 93-102.

[2] M. Kim, "A Qualitative Multiple Case Study on the Participation Structure and Interactions in College Courses with Active Student Participation", The Korean Journal of Educational Psychology, vol. 29, no. 1, (2015), pp. 135-168.

[3] J. Lee, C. Lim and H. Kim, "Development of an Instructional Design Model for Flipped Learning in Higher Education", Educational Technology Research Development, vol. 65, pp. 427-453.

[4] E. Holzer, "Welcoming Opposition: Havruta Learning and Montaigne's the Art of Discussion", Journal of Moral Education, vol. 44, no. 1, (2015), pp. 64-80.

[5] R. Shargel and B. P. Laster, "Partner Learning (Havruta) for Close Reading Comprehension", English Journal, vol. 105, no. 3, (2016), pp. 63-68.

[6] O. Kent, "A Theory of Havruta Learning”, Journal of Jewish Education, vol. 76, no. 3, (2010), pp. 215-245.

[7] S. Genut and Y. B. Kolikant, "Undergraduate Haredi Students Studying Computer Science: Is their Prior Education Merely a Barrier?", Interdisciplinary Journal of E-Skills and Lifelong Learning, vol. 13, (2017), pp. 197-214.

[8] L. M. Barker, "Under Discussion: Teaching Speaking and Listening”, English Journal, vol. 105, no. 1, (2015), pp. 87-89. 